\title{
HOTS-Based English Learning Worksheet for Elementary School Students
}

\author{
Putu Kerti Nitiasih ${ }^{1}$ Luh Gd Rahayu Budiarta ${ }^{1, *}$ Ni Luh Putu Era Adnyayanti ${ }^{1}$ \\ ${ }^{1}$ English Language Education Study Program, Universitas Pendidikan Ganesha, Singaraja, Indonesia \\ "Corresponding author.Email: rahayu.budiarta@undiksha.ac.id
}

\begin{abstract}
The revised 2013 curriculum in Indonesia emphasizes HOTS-based learning. Therefore, the teacher's skill, techniques, methods, media, and books must support the student's critical thinking. In the learning process, the teacher usually uses the student's worksheet. However, some educational practitioners are not convinced that the activities contain of student's worksheet appropriate with the HOTS criteria. Based on the researcher's observation, there are many questions with LOTS types especially in multiple-choice questions for students. This study was aimed at developing students' higher order thinking skills in English learning process through the use of students' worksheets for fourth-grade students at the elementary school level. The ADDE models were employed in this investigation. As the subject of this study, the teacher and fourth-grade elementary school students in Buleleng Regency were participating. The HOTS students' worksheets based on English learning were arranged by considering the adapted blue print from $4^{\text {th }}$ grade English syllabus. The data were collected through several techniques, such as; observation, interview, document analysis, expert judgment, and questionnaire. The result of this study showed that this book gave positive response by stating that the book was categorizes as excellent in which it presented the material based on the syllabus and it had an interesting design. The HOTS' worksheet book that was developed in this study was expected as a medium for learning English that facilitated elementary school teachers and students.
\end{abstract}

Keywords: Students' worksheet, HOTS based English learning, elementary school students

\section{INTRODUCTION}

The 2013 Curriculum requires schools to develop students' $4 \mathrm{C}$ talents in the 21 st century competencies [1]. These qualities include critical thinking, communication, creativity, invention, and teamwork. The learning environment has changed dramatically in recent years. The needs of the twenty-first century have modified various learning traits and competencies. The focus of education has shifted from teachers to students [2],[3]. It necessitates the teacher creating more advanced learning activities.

HOS (higher-order thinking skills) are one of the competences that are highlighted in the education 4.0 model. As a framework for dealing with global concerns [4], HOTS has a significant role to play in learning systems. The integration of HOTS into the teachinglearning process is an attempt to raise the cognitive levels of students in the process of learning. According to other study, students' interest and achievement are boosted when they have higher-order thinking skills [5].
Lower Order Thinking Skills (LOTS) and Higher Order Thinking Skills (HOTS) are the two categories of cognitive levels based on the revised Taxonomy Bloom results: Lower Order Thinking Skills (LOTS) and Higher Order Thinking Skills (HOTS). Remembering (C1), comprehending (C2), and implementing (C3) are the components of LOTS, whereas HOTS is composed of analyzing (C4), evaluating (C5), and creating (C6).

One of the strategies to produce a better generation is to encourage students' critical thinking from elementary school. The 2013 curriculum is being implemented as a means of achieving HOTS in primary education. It is a clear attempt to raise pupils' learning levels at a young age. Improved integrated learning processes employing a scientific method with the introduction of higher-order thinking skills is one transformative feature of the 2013 primary school curriculum.

Students' Higher-Order Thinking Skills can be developed through the appropriate teaching strategies and knowledge sources. The HOTS should be attached 
in the development of knowledge-resources provided for students and the learning activities are formed to build students' understanding and apply their knowledge toward real life situations [6]. In developing the activities for elementary students, the teacher can use various media like a worksheet. Integrating the worksheet for learning process with 21 st century learning the teacher can use higher order thinking skills material. Higher order thinking skills is the skills that require problem solving, create decisions, evaluating, innovating and creating something [1]. Higher-order thinking skills are more than just memorizing facts or retelling stories. Memorizing facts or repeating are lowlevel thinking skills because kids are like robots who merely repeat what they learn and do what they are instructed [7]. Drawing inferences, connecting with additional facts and concepts, manipulating, categorizing, combining, and applying them to new issues [7]. HOTS encompasses critical, reflective, metacognitive, creative, decision-making, and problemsolving skills [8]-[11].

The higher order thinking skills trigger the creative thinking that uses the mind to produce or create new thing [12]. A worksheet with higher order thinking skills helps the students to improve the critical thinking skills including with the 21 st century learning. There are few studies that discuss a worksheet consist of higher order thinking skills for elementary students. The previous studies conducted about the development of module for weak ESL learner in writing [13]. The finding showed that higher order thinking skills module provides a guideline for the teacher to apply the thinking skills in the process of teaching writing. Based on the HOTS' module that was used by the teacher, the students enjoyed the strategy and gives comment that the worksheet helps them to write a better. Using HOTS' module also encourages the collaborative in term working in group with other students. It indicated that higher order thinking skills worksheet rise the students' capability in learning process. Another researcher had conducted research regarding the use of HOTS' worksheet in thermodynamics material, the result of the study manifested that HOTS' worksheet is feasible to use in delivering thermodynamics material with the average score of $89 \%$ which is categorized good [14]. The other researcher focuses on higher order thinking skills questions in teaching reading [15]. The result of the study displayed those students and teacher communicates very well during the lesson, the interactions between the teacher and students have obviously happen. Besides, the students' answer is in line with the thinking skills from the bloom taxonomy in HOTS.

Regarding the previous study that has conducted research related with the development of higher order thinking skills material, one of the elementary schools in Buleleng has apply the higher order thinking skills during the learning process but it is not maximal. The teacher tries to implement the higher order thinking skills during the learning process but it is not easy, the sources of material are limited and the learning process still the teacher centred. Lack of material sources is one of the biggest challenges that are encountered by the teacher such as the higher order thinking skills' worksheet to teach the students. However, relating the current problem with previous research, the researcher has not found the study that discuss about developing worksheet for students' fourth-grade elementary students based on higher order thinking skills. Therefore, this study was developed based on the gap. The worksheet that consisted with higher order thinking skills expect to enhance the creativity and critical thinking skills from the students. The activities or the topic was developed based on syllabus used in the school.

\section{METHOD}

This study used Design and Development (D\&D) as the research design. Design and Development is an organized design, development, and assessment technique that includes creating instructional and noninstructional products and tools, modified or new developmental models. In this D\&D research with ADDE (Analysis, Design, Development, and Evaluation) model, there are 4 phases carried out to develop a prototype of the English Activity Book for students grade 4 elementary school [16]. In analysis phase, observation and interview were conducted with the teacher of elementary school of SDN 1 Banyuasri. This school was used as a setting meanwhile the English teacher and several elementary school students grade 4 were selected using the random sampling method as research subjects. The principle of this simple random sampling is every object has the same opportunity to be used and selected. The observation was made to find out the information that the researcher needs to support this study. The researchers consider several aspects to being develop of student worksheets, including curriculum analysis, topic analysis, and student analysis. Curriculum analysis is carried out to see the compatibility of student worksheets with the curriculum in the school. In the topic analysis, is carried out to see and determine the indicators to be achieved in student worksheets according to the topic chosen. The last is student analysis, at this stage the researchers examined the character and ability of students to be able to develop a student worksheet based on higher order thinking skills.

After analysing the needs and problems that occur in the field, the next phase is designing phase. In this stage, the worksheets are designed based on HOTS by involving the topic and materials from the syllabus analysis. The design was made regarding to the 
materials taught by the teacher and was developed deeper by providing suitable learning activities that can train their skills, especially thinking skills with highlevel categories.

The next stage was product development based on the designs that have been made. In the development phase of student worksheets, it starts from make student worksheets. The initial draft of students' worksheet developed in the design phase was judged by the experts in terms of its relevancy. The result of the expert judgment was used to revise the initial draft, which then developed into a final draft. This final draft was developed until it became a final product in the form of students' worksheet.

The last step was evaluation. This evaluation aimed to find the effectiveness of the produced product to improve the critical ability of elementary students in learning English. In the evaluation phase, this phase consists of expert review, one to one, and small groups. Comments and suggestions that are given by experts and students it will be revised to develop student worksheets based on higher order thinking skills. The expert judgment and questionnaire were used to find out the quality of the product.

The data were collected through several techniques, such as; observation, interview, document analysis, expert judgment, and questionnaire. The instruments used in gaining the data were syllabus, observation sheet, interview guide, check-list for content validity, rubric for product quality, and questionnaire.

\section{RESULTS AND DISCUSSION}

This study produced a product in the form of a student worksheets HOTS-based for learning English for fourth grade of elementary school students. This research is development research with ADDE model that consists of four steps; analysis, design, development, and evaluation.

\subsection{Analysis Phase}

The analysis phase is carried out by the researcher analysing the curriculum, topic, and students. Curriculum analysis is carried out by researchers looking for core competencies, basic competencies, indicators of competency achievement, and time allocation applied in SD 1 Banyuasri. The document analysis was conducted in order to understand the content and learning objectives as suggested on the syllabus. The results of analysis were used to design and to develop the content of the worksheet. As a result, the product's content may meet the needs of students. In this study, the document was the syllabus of the second semester of fourth-grade Elementary School. The data required for the designing process was gathered through analyse the second semester of fourth-grade elementary school English syllabus. The results indicated that the syllabus for the second semester of fourth grade elementary students includes 4 topics. The topics are things in the classroom, animals, job and electronic appliance in the house.

\subsection{Design Phase}

Student worksheets are designed in accordance with basic competencies and indicators that have been analysed. The blueprint for the worksheet design was made by reflecting the results of the syllabus analysis. In this blueprint, the materials and themes of each topic were decided. The blueprint designed used in the students' worksheet must be according to the level of the student and insert HOTS based activities. Table 1 showed about designing the first topic about things in the classroom.

\subsection{Development Phase}

This stage is related to manufacturing products in the form of HOTS-based student worksheets. The student worksheets are designed HOTS-based by using the steps of solving the problem in the settlement contained in student worksheets. The characteristics of this student worksheets are (1) cover, (2) title, (3) work instructions, (4) language focus and skills, (5) supporting information, (6) activities that contain issues HOTS-based. The development process of the students' worksheet used Adobe Photoshop software. There were several steps in developing HOTS-based students' worksheet book. First, prepare sources, pictures, and all media to support the development of the students' worksheets. It was the first step that must be completed in order to build the worksheet effectively. The source took the form of a syllabus analysis result. The pictures or photos are required for the worksheet's illustration has had copyright licence by buying this in freepik.com to provide the activity of the worksheet. The design was intended to attract the reader's attention and help them in understanding the context of the students' worksheet. Then, construct the content of the students' worksheet. The students' worksheet was designed in A4 shape of paper. It contains four central units as the expectation of English teachers known from the result of the syllabus analysis. Figure 1 and Figure 2 are the design of the student's worksheet. Figure 3 and Figure 4 are the example of the topic and instruction given in the worksheet. 
Table 1. Topic 1: Things in the Classroom

\begin{tabular}{|c|c|c|c|}
\hline $\begin{array}{c}\text { Basic } \\
\text { Competency } \\
\end{array}$ & $\begin{array}{c}\text { Bloom } \\
\text { Taxonomy }\end{array}$ & Activities & Activities in the Classroom \\
\hline $\begin{array}{l}\text { 1. Speaking, conversing } \\
\text { in learning activities in } \\
\text { the classroom }\end{array}$ & C4 (Analyse) & $\begin{array}{l}\text { Analyzing, identifying, } \\
\text { and finding. }\end{array}$ & $\begin{array}{l}\text { Meet 1: Please find the images with } \\
\text { their respective descriptions. } \\
\text { Please make a connecting line } \\
\text { between the images and descriptions } \\
\text { with a different color. } \\
\text { Meet 2: Please identify the stacked } \\
\text { images below correctly and enter them } \\
\text { into their respective fields. } \\
\text { Meet 3: Please circle the differences in } \\
\text { the pictures. }\end{array}$ \\
\hline $\begin{array}{l}\text { 2. Reading understanding } \\
\text { the contests of the text } \\
\text { about activities in the } \\
\text { classroom }\end{array}$ & C5 (Evaluation) & $\begin{array}{l}\text { Predicting and } \\
\text { justifying. }\end{array}$ & $\begin{array}{l}\text { Meet 1: Please sort the wrong image } \\
\text { below into the correct image order. } \\
\text { Meeting 2: Please write numbers to join } \\
\text { the questions and answers. }\end{array}$ \\
\hline $\begin{array}{l}3 . \quad \text { Writing, writing in } \\
\text { words related } \\
\text { activities }\end{array}$ & C6 (Creating) & $\begin{array}{l}\text { Categorizing and } \\
\text { arranging. }\end{array}$ & $\begin{array}{l}\text { Meet 1: Please categorize the images } \\
\text { below according to groups. } \\
\text { Meet 2: Please arrange the random } \\
\text { sentences below in the correct order. }\end{array}$ \\
\hline
\end{tabular}

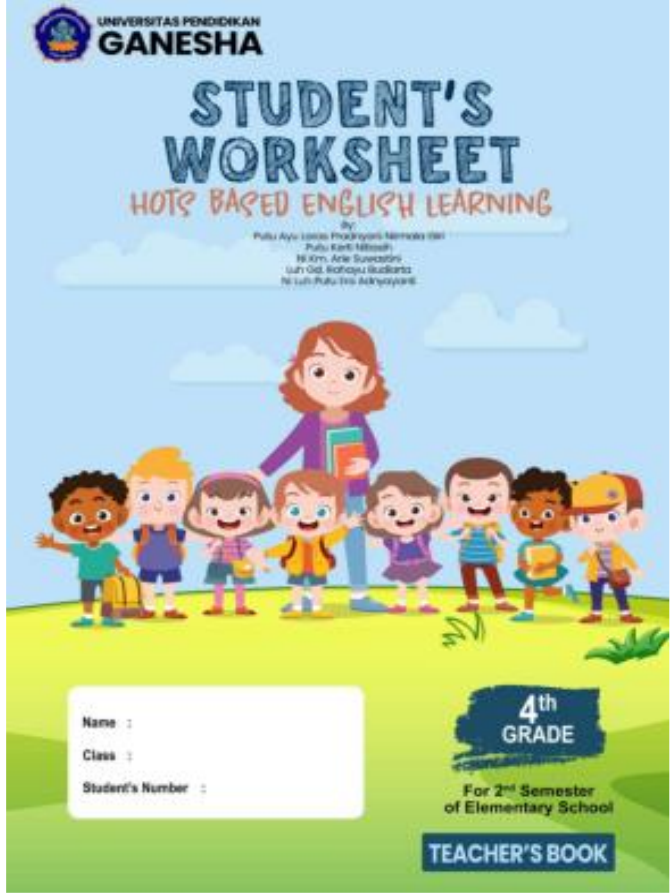

Figure 1 Cover of Students’Worksheet

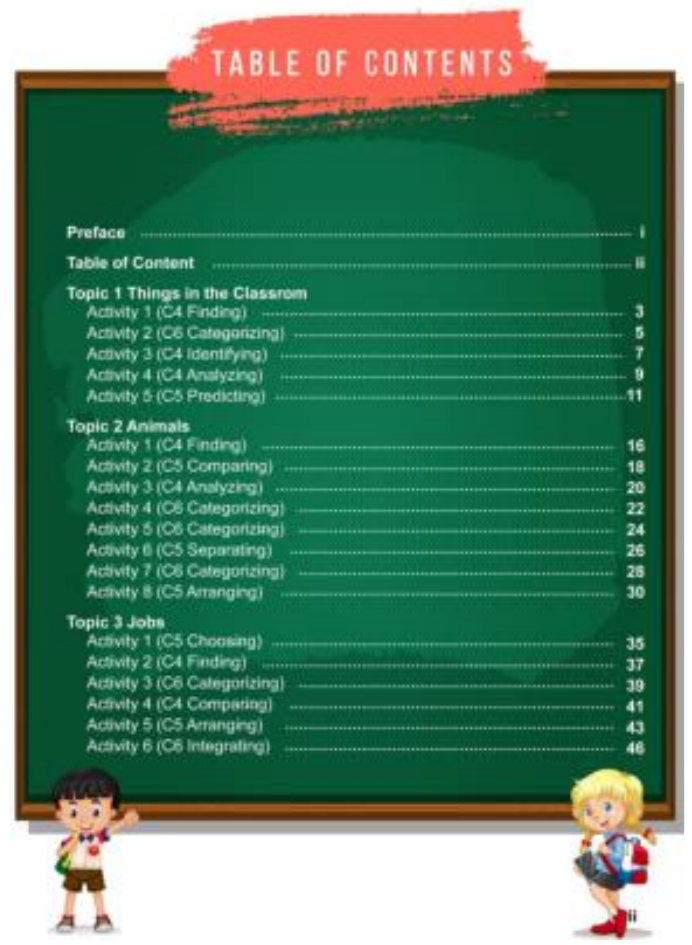

Figure 2 Table of Contents 


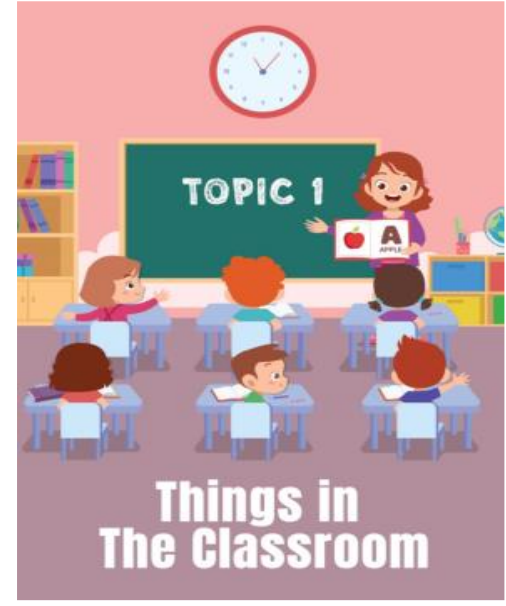

Figure 3 Example of the topic

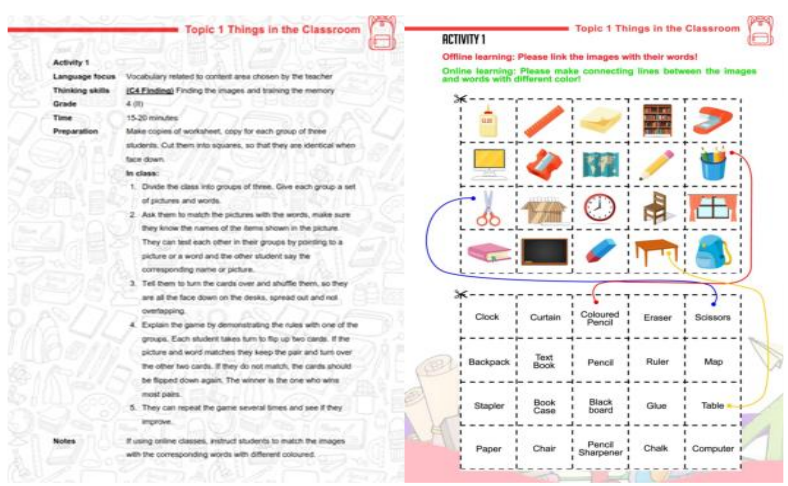

Figure 4 Example of Instruction and Activities

\subsection{Evaluation Phase}

Evaluation process contained the evaluation from the expert's judgement, quality judgement and user review through the questionnaire. The experts were the expertise who expert in material development. The first of expert judgement showed that from all the items of expert judgement that consisted of 32 items, all the items were relevant to the material. The expert determines the items in the worksheet were relevant with the total score 1, calculated using Gregory formula. It means that the worksheet prepared for the elementary students were excellent. The second expertise was the expert for quality judgement. The total score for each expert were excellent and good. The first expert categorized the worksheet was excellent with the total score 155 , the second expert consider the worksheet as excellent worksheet with total score of 145, the third lecturer decided the worksheet in good criteria with 138 as the total score.

All experts agreed that the worksheet prepared were excellent. Therefore, the teacher can use this worksheet for teaching English based on higher order thinking of the students. On the other hand, the result of quality judgement from the users' review that was obtained from the questionnaire indicated excellent category. The questionnaire contained 10 items for the teacher and 10 items for the students. The teacher that involved as the participant claimed that the worksheet was excellent in teaching English for sixth-grade elementary school students with the average score 49 . Moreover, the result from the students manifested that the first student revealed 49 as the average score and it was categorized excellent worksheet. The second students obtained 47 as the average score and it belongs to excellent worksheet. The third student gained 45 as the average score and it means excellent worksheet, the fourth student acquired 46 as the average students and belongs to excellent worksheet, the sixth students obtained 40 as the average score which means good worksheet. Based on the result of quality judgement from the teacher and students, the higher order thinking skills worksheet was excellent for teaching the materials namely things in the classroom, animals, job and electronic appliance in the house.

\subsection{Discussion}

The HOTS-based students' worksheet in the fourth grade students of elementary school are designed by adapting ADDE model. Based on the results that were obtained, it acquired that the development of higherorder thinking skills was still low in SD N 1 Banyuasri. It can be stated that the implementation of HOTS by the English teacher was not going well, because the teacher encountered challenges during teaching the students because of limited sources of material. In addition, the teacher did not associate the higher order thinking skills in the activity. These challenges should be solved by the teacher using an interactive activity like various teaching strategies or a worksheet that consisted with higher order thinking skills.

Integrating the critical thinking skills with activities can result a good outcome for the development of students' critical thinking. By giving the students the right activity can help the students to construct knowledge, applying in real world and use it properly [17]. By those activities, it assists the students to learning higher order thinking skills.

This designed materials, is categorized as excellent based on the quality judgement and users' review. It means that the worksheet that is consisted with higher order thinking skills it is feasible to use for increasing the higher order thinking skills [18]. The higher order thinking skills in the worksheet escalate the creation of knowledge, analytical thinking, problem solving and critical thinking skills [19].

A higher order thinking skill gave the students to learn productively with other students and they can assess themselves by learning with other students. In the students' worksheet that is based on higher order thinking skills, the researcher also develops the student to work in group collaboratively. By working 
collaboratively, the students can generate their ideas in the discussion session with the other students. Generating ideas is important for the students due to communication skills, a higher order thinking skill assist student to generate their ideas. The students have problem in generating ideas because of exercise in generating idea, specialized skill and lack of information [20]. These problems can be solved by helping the students to learn higher order thinking skills through teaching, learning environment and selfdirected learning. Working in group through collaborative strategy that implement higher order thinking skills could increase the student's motivation, collaboration, thinking critically and social skills [21]. It means that through the worksheet the students could learn those skills with the others. It is beneficial for the students that can train the critical thinking skills, positive attitude and problem solving. This in line with the findings from previous researcher states that collaborative learning that is integrated with higher order thinking skills also could improve low level proficiency of the students [2].

Besides learning with group, the students also could improve the self-learning from the students' worksheet based on higher order thinking skills. The students could be more independent during the learning process, by using higher order thinking skills, it encourages the students to be more independent and use the authentic material in daily life to learn [22]. The student think independently and also can discuss it with the other students. This happened because the students underwent the several stages like observing, forming the answer, analyse the process and provides conclusion. It means that by using higher order thinking skills in worksheet, the students are helped by those skills during the learning process.

Moreover, the use of higher thinking skills worksheet avoids the bored situation in the classroom. Boring situation decreased the students' interest in learning process, they did not pay attention to the teacher. Boring situation happed because there was no challenging for the students during the learning process, the students also has not use optimally by the teacher. If the students' cognitive is limited to the learning activities such as remembering and understanding, the boredom situation [23]. The boredom situation in the classroom happened due to the lack of participation in the class; less participation could come from less attractive activities from the learning process. By providing an attractive activity, the students would entertain and follow the lesson properly.

The implication of this study is developing the students' worksheet based on higher order thinking skills for fourth-grade elementary students in order to enhance their critical thinking skills, creative thinking, problem solving and working collaboratively. The teacher could improve the worksheet by adjusting the students' cognitive based on the material. Moreover, in developing the worksheet the teacher should determine the blueprint of the worksheet and designing an attractive activity for the students. Considering the development of higher order thinking skills worksheet for fourth-grade elementary students is still limited for the teacher, the minister of education might create a program, workshop or internship for the teacher to increase the knowledge related to higher order thinking skills. This activity could escalate the application of higher order thinking skills for the students. Moreover, the teacher can create community that focus to develop higher order thinking materials for elementary students.

\section{CONCLUSION}

The Students' Worksheet HOTS-Based English Learning was developed by using D\&D research with ADDE (Analysis, Design, Development, Evaluation) model. The results of the analysis at the beginning of this development research revealed that some educational practitioners are not convinced that the activities contain of student's worksheet appropriate with the HOTS criteria. Based on the researcher's observation, there are many questions with LOTS types especially in multiple-choice questions for students.

To develop students' higher order thinking skills in English Learning process, this worksheet was developed into several activities, such as: analysing (C4), developing (C5), and creating. (C6). This book gave positive response by stating that the book was categorizes as excellent in which it presented the material based on the syllabus and it had an interesting design

The result of comments and suggestions are used to revise student worksheets so that the HOTS-based student worksheets become well. For students who desire to improve their creativity, problem-solving skills, collaborative skills, and higher-order thinking skills can use this HOTS book product. The other researchers can conduct similar research at the students' higher level in more prominent parts and broader research objects because the study's outcome depends on students' worksheet HOTS.

\section{ACKNOWLEDGMENT}

The authors of this research would like to express their gratitude to the Ganesha University of Education Bali, Indonesia which support this research. They are also very grateful toward the commitments of the teacher and students during conducting this research. All are highly appreciated. 


\section{REFERENCES}

[1] Nofrion, N., \& Wijayanto, B. (2018). Learning Activities in Higher Order Thinking Skill (Hots) Oriented Learning Context. Geosfera Indonesia, 3(2),122. https://doi.org/10.19184/geosi.v3i2.8126

[2] Ali, Z. (2018). A Case Study on Collaborative Learning to Promote Higher Thinking Skills (HOTS) among English as a Second Language (ESL) Learners. Jurnal UMP: Social Sciences and Technology Management,1(1), 1-14. http://umpir.ump.edu.my/5069/

[3] Ichsan, I. Z., Sigit, D. V., Miarsyah, M., Ali, A., Arif, W. P., \& Prayitno, T. A. (2019). HOTS-AEP: Higher order thinking skills from elementary to master students in environmental learning. European Journal of Educational Research, 8(4), 935-942. https://doi.org/10.12973/eu-jer.8.4.935

[4] Tyas, M. A., Nurkamto, J., \& Marmanto, S. (2020). Cultivating Students' Higher-Order Thinking Skills in EFL Classes: The Role of the Teacher and the Textbook. International Online Journal of Education and Teaching, 7(1), 267-276.

[5]Alsowat, H. (2016). An EFL flipped classroom teaching model: Effects on English language higher-order thinking skills, student engagement and satisfaction. Journal of Education and Practice, 7(9), 108-121.

[6] Thamrin, N. R., Widodo, P., \& Margana. (2019). Developing Higher Order Thinking Skills (Hots) for Reading Comprehension Enhancement. Journal of Physics: Conference Series, 1179(1). https://doi.org/10.1088/1742-6596/1179/1/012073

[7] Thomas, A., \& Thorne, G. (2009). How to increase higher level thinking | center for development and learning. The Center for Learning and Development Blog. Retrieved from http://www.cdl.org/articles/how-to-increase-highorder-thinking/

[8]King, F. J., Goodson, L., \& Rohani, F. (1998). Higher Or-der Thinking Skills. Publication of the Educational Services Program, Now Known as the Center for Advancement of Learning and Assessment. Obtido de: Www.Cala.Fsu.Edu, 1176. Retrieved from http://www.cala.fsu.edu/files/higher_order_thinking_skills.pdf

[9]Nguyen, T. (2018). Teachers, Capacity of Instruction for Developing Higher - Order Thinking Skills for Upper Secondary Students - A Case Study in Teaching Mathematics in Vietnam, 10(1), 8-19.
[10] Snyder, L. G., \& Snyder, M. J. (2008). Teaching critical thinking and problem solving skills. The Delta Pi Epsilon Journal, L(2), 90-99. https://doi.org/10.1023/A:1009682924511

[11] Miri, B., David, B. C., \& Uri, Z. (2007). Purposely teach-ing for the promotion of higher-order thinking skills: A case of critical thinking. Research in Science Education, 37(4), 353-369. https://doi.org/10.1007/s11165-006-9029-2

[12] Nachiappan, S., Damahuri, A. A., Ganaprakasam, C., \& Suffian, S. (2018). Application of Higher Order Thinking Skills (Hots) in Teaching and Learning Through Communication Component and Spiritual, Attitudes and Values Component in Preschool. International Journal of Early Childhood Education and Care, 7(December), 2432.

[13] Singh, C. K. S., Singh, R. K. A., Singh, T. S. M., Mostafa, N. A., \& Mohtar, T. M. T. (2018). Developing a Higher Order Thinking Skills Module for Weak ESL Learners. English Language Teaching, $11(7), \quad 86$ https://doi.org/10.5539/elt.v11n7p86

[14] Nadhiroh, N., \& Latifah, S. (2020). Higher Order Thinking Skills (HOTS)-Based Students' Worksheets in Thermodynamics Materials. Indonesian Journal of Science and Mathematics Education, 3(1), 87-95. https://doi.org/10.24042/ijsme.v3i1.6082

[15] Mintre, R., \& Lie, A. (2020). Higher Order Thinking Questions in Teaching Reading in a Private Primary School. Beyond Words, 8(1), 3646.

http:/journal.wima.ac.id/index.php/BW/article/vie w/2092

[16] Richey, R. C., \& Klein, J. D. (2007). Design and Development Research. In BMC Public Health (Vol. $\quad 5, \quad$ Issue 1 ). https://ejournal.poltektegal.ac.id/index.php/siklus/a rticle/view/298\%0Ahttp://repositorio.unan.edu.ni/2 986/1/5624.pdf\%0Ahttp://dx.doi.org/10.1016/j.jana .2015.10.005\%0Ahttp://www.biomedcentral.com/1 $471-$

2458/12/58\%0Ahttp://ovidsp.ovid.com/ovidweb.cg $\mathrm{i} ? \mathrm{~T}=\mathrm{JS} \& \mathrm{P}$

[17] Vijayaratnam, P. (2012). Developing Higher Order Thinking Skills and Team Commitment via Group Problem Solving: A Bridge to the Real World. Procedia - Social and Behavioral Sciences, 66, 5363. https://doi.org/10.1016/j.sbspro.2012.11.247

[18] Yennita, Y., Khasyyatillah, I., Gibran, G., \& Irianti, M. (2018). Development of worksheet based on 
high-order thinking skills to improve high-order thinking skills of the students. Journal of Educational Sciences, 2(1), 37. https://doi.org/10.31258/jes.2.1.p.37-45

[19] Kwangmuang, P., Jarutkamolpong, S., Sangboonraung, W., \& Daungtod, S. (2021). The development of learning innovation to enhance higher order thinking skills for students in Thailand junior high schools. Heliyon, 7(6), e07309. https://doi.org/10.1016/j.heliyon.2021.e07309

[20] Heong, Y. M., Yunos, J. M., Othman, W., Hassan, R., Kiong, T. T., \& Mohamad, M. M. (2012). The Needs Analysis of Learning Higher Order Thinking Skills for Generating Ideas. Procedia Social and Behavioral Sciences, 59, 197-203. https://doi.org/10.1016/j.sbspro.2012.09.265

[21] Susanti, A., Retnaningdyah, P., Ayu, A. N. P., \& Trisusana, A. (2020). Improving EFL Students' Higher Order Thinking Skills Through Collaborative Strategic Reading in Indonesia. International Journal of Asian Education, 1(2), 4352. https://doi.org/10.46966/ijae.v1i2.37

[22] Purnama, S., Faelasofi, R., Al-munawwarah, S. F., \& Suardi, I. (2020). Development of English Teachers Oriented Higher Order Thinking Skills ( Hots ) In Elementary School of Madrasah Ibtidaiyah ( MI ). 12(2), 3581-3590.

[23] Bakry, \& Md Nor Bakar. (2015). The process of think-ing among Junior High School students in solving HOTS question. International Journal of Evaluation and Research in Education (IJERE), 4(3), 138-145. 